\title{
PENGARUH STATUS LENGAS TANAH TERHADAP PERTUMBUHAN DAN PRODUKSI TANAMAN SEMANGKA LOKAL
}

\author{
Dedi Erawan ${ }^{1)}$ dan Tresjia C. Rakian ${ }^{1)}$ \\ ${ }^{1)}$ Dosen Fakultas Pertanian, Universitas Halu Oleo, Kendari \\ ${ }^{1)}$ Corresponding Email : erawan_ddi@yahoo.com
}

\begin{abstract}
Watermelon fruit is favored because of its sweet and fresh fruit flavor, but in the market it is often found the taste of watermelon that is less sweet (tasteless). The sweet taste of watermelon is much influenced by environmental conditions, especially climate factors (rainfall). Generally fruit produced from areas with high rainfall often produces a less sweet taste. This study aims to determine the effect of soil moisture status on the growth and production of local watermelons. This study was compiled based on a Randomized Block Design (RBD) with 3 replications. The treatment given is soil moisture status, consisting of 4 levels, namely: L1 $=$ KAT $100 \%$ of field capacity, L2 $=$ KAT $80 \%$ of field capacity, L3 $=$ KAT $60 \%$ of field capacity and L4 $=$ KAT $40 \%$ of field capacity. Observation data were analyzed using variance ( $F$ test) $5 \%$ real level and continued with further BNT test at the $5 \%$ test level. The results showed that soil moisture status and potassium fertilizer dosage had a significant effect on plant height at 4, 6 da, 8 weeks after planting and gave a significant effect on leaf area at 6 weeks of age.
\end{abstract}

Keywords: Soil moisture, Watermelon.

\begin{abstract}
Abstrak
Buah semangka disukai karena rasa buahnya yang manis dan segar, namun dipasaran sering dijumpai rasa buah semangka yang kurang manis (tawar). Rasa manis buah semangka banyak dipengaruhi oleh kondisi lingkungan, terutama factor iklim (curah hujan). Umumnya buah yang dihasilkan dari daerah dengan curah hujan tinggi sering menghasilkan rasa yang kurang manis. Penelitian ini bertujuan untuk mengetahui pengaruh status lengas tanah terhadap pertumbuhan dan produksi buah semangka lokal. Penelitian ini disusun berdasarkan Rancangan Acak Kelompok dengan 3 kali ulangan. Perlakuan yang diberikan adalah status lengas tanah, terdiri dari 4 taraf yaitu : $\mathrm{L}_{1}=\mathrm{KAT} 100 \%$ dari kapasitas lapang, $\mathrm{L}_{2}=\mathrm{KAT} 80 \%$ dari kapasitas lapang, $\mathrm{L}_{3}=\mathrm{KAT} 60 \%$ dari kapasitas lapang dan $\mathrm{L}_{4}=\mathrm{KAT} 40 \%$ dari kapasitas lapang, Data pengamatan dianalisa dengan menggunakan sidik ragam (uji $\mathrm{F}$ ) taraf nyata $5 \%$ dan dilanjutkan dengan uji lanjut BNT pada taraf uji $5 \%$. Hasil penelitian menunjukan bahwa status lengas tanah dan dosis pupuk kalium memberikan pengaruh nyata terhadap tinggi tanaman pada umur 4, $6 \mathrm{da}$, 8 minggu setelah tanam dan memberikan pengaruh nyata terhadap luas daun pada umur 6 minggu.
\end{abstract}

Kata Kunci : Lengas Tanah, Semangka. 


\section{PENDAHULUAN}

Tanaman semangka (Citrulullus Vulgaris L.) termasuk ke dalam tanaman hortikultura yang mempunyai nilai jual tinggi dan permintaan pasar yang terus meningkat sehingga memiliki prospek yang baik untuk dibudidayakan. Semangka banyak digemari oleh berbagai lapisan masyarakat karena rasanya yang manis, aromanya yang khas, dan mengandung banyak air, selain itu juga merupakan sumber vitamin $A$, dan $C$. Permintaan pasar yang tinggi belum dapat dipenuhi oleh daerah sentra produksi maupun produksi lokal yang memadai. Berbagai upaya untuk memenuhi permintaan buah semangka terus dilakukan, seperti melalui perluasan areal tanam dan peningkatan produktifitas buah semangka.

\section{Daerah Provinsi Sulawesi}

Tenggara, untuk pengembangan areal tanaman umumnya dilakukan pada tanah ultisol (Podzolik Merah Kuning) beriklim kering dengan curah hujan terbatas, serta sebaran curah hujan yang tidak teratur. Oleh karena itu, pengembangan pertanaman semangkadisulawesi tenggara menjadi strategis, mengingat semangka termasuk tanaman iklim kering tetapi membutuhkan ketersediaan air yang cukup sepanjang musim pertumbuhannya.

Sebagai buah segar, semangka disukai karena rasa manisnya, semakin manis rasa buah semakin tinggi nilai jualnya. Namun dipasaran sering kita jumpai rasa yang bervariasi antara manis hingga kurang manis (tawar) terutama dari jenis semangka lokal. Umumnya buah yang dihasilkan dari daerah dengan curah hujan tinggi menghasilkan rasa yang kurang manis dibanding buah yang dihasilkan dari daerah kering. Sejalan dengan itu, Thompson and Kelly (1978), menyatakan bahwa untuk mendapatkan buah dengan rasa yang manis diperlukan keadaan iklim yang panas, kering dan bercahaya penuh, sehingga pemberian air pada budidaya semangka merupakan hal penting yang perlu diperhatikan dalam upaya peningkatan mutu buah semangka lokal.

Melalui upaya peningkatan produktifitas dan kualitas hasil buah semangka, perlu ditunjang dengan ketersediaan hara yang cukup terutama unsur kalium. Kalium selain berperan dalam proses metabolisme dalam tubuh tanaman, disinyalir berperan juga dalam meningkatkan efisiensi penggunaan air (ketahanan tanaman pada masa kekeringan), dan memperbaiki ukuran serta kualitas buah pada masa generatif serta menambah rasa manis dan enak pada buah. Menurut Prajnanta (2001), tanaman semangka dalam proses budidaya membutuhkan kalium lebih banyak dibandingkan nitrogen dan fosfor. Peningkatan produksi secara optimal, perlu dipadukan teknologi budidaya yang mengarah kepada perbaikan hasil dan kualitas yang memadai pada skala usaha tani yang menguntungkan. Oleh karena itu perlu diteliti hubungan ketersediaan lengas 
tanah dan pemberian pupuk kalium dalam upaya meningkatkan kualitas rasa buah semangka, terutama dari jenis semangka lokal sehingga mempunyai daya saing tinggi di pasaran baik lokal maupun internasional.

\section{TUJUAN DAN MANFAAT}

Tujuan penelitian adalah

Mempelajari pertumbuhan semangka pada tingkat lengas tanah yang berbeda (2) mengetahui kondisi lengas tanah terbaik terhadap pertumbuhan semangka (3) mengembangkan sumberdaya lahan kering untuk usaha tani hortikultura yang mempunyai nilai jual tinggi khususnya tanaman semangka.

Penelitian ini memiliki manfaat sebagai :

1. Pengembangan pertanian lahan kering khususnya di wilayah Sulawesi Tenggara untuk peningkatan produk hortikultura dan memberi peran penting bagi kehidupan daerah baik dari aspek ekonomi, sosial, budaya maupun pelestarian keseimbangan lingkungan.

2. Pengembangan dan perluasan tanaman semangka local untuk meningkatkan produksi, pemanfaatan sumber daya lahan (terutama lahan kering) dan peningkatan pendapatan masyarakat.

3. Pengembangan potensi peningkatan produksi semangka di Sulawesi Tenggara, berbasis kandungan lengas tanah sehingga dapat meningkatkan produktifitas lahan.

\section{METODE PENELITIAN}

\section{Waktu dan Tempat}

Penelitian dilaksanakan pada rumah plastik di Kebun Percobaan Fakultas Pertanian dan Laboratorium Agroteknologi Fakultas Pertanian UHO, berlangsung dari bulan Agustus sampai bulan Oktober 2012.

\section{Bahan dan Alat}

Bahan yang digunakan: benih semangka, pupuk kandang kotoran sapi, Urea, SP36 dan $\mathrm{KCl}$, kapur, pestisida, tanah ultisol, air, polibag hitam dan bahan pendukung lainnya. Sedangkan alat-alat yang akan digunakan ; cangkul, garpu dan parang, mini spayer, selang, pipa, ember platsik, timbangan, soil moisture meter, $\mathrm{pH}$ meter, meteran, gelas ukur, dan oven.

\section{Metode Penelitian}

Penelitian disusun menurut Rancangan Acak Kelompok yaitu status lengas air tanah yang diulang sebanyak 3 kali ulangan, Lengas tanah yang diujicobakan terdiri dari 4 taraf, yaitu $\mathrm{L} 1=$ KAT $100 \%$ kapasitas lapang, L2 = KAT $80 \%$ dari kapasitas lapang, L3 $=$ KAT $60 \%$ dari kapasitas lapang dan L4 = KAT 40\% dari kapasitas lapang. Masing-masing perlakuan diulang sebanyak 3 ulangan sehingga diperoleh 12 unit percobaan.

Media tanam menggunakan tanah tipe regosol dari daerah Boyolali. Tanah dikering anginkan dan diayak. Setelah ditimbang masing-masing seberat $5 \mathrm{gr}$, tanah dimasukkan ke dalam polibag. 
Tanah kemudian diukur kapasitas lapangnya dengan metode gravimetri (penimbangan). Pupuk dasar yang dipakai adalah $12,5 \mathrm{mg}$ urea, $37,5 \mathrm{mg}$ TSP, dan $37,5 \mathrm{mg} \mathrm{KCl}$. Pemeliharaan rutin yang dilakukan meliputi penyiraman sesuai prosedur berikut :

\section{- Aplikasi perlakuan}

Penyiraman untuk mengatur lengas tanah dilakukan sesuai dengan masing-masing perlakuan. Penyiraman dilakukan setiap hari secara bersamaan pada semua tanaman uji.

\section{- Pengamatan}

Komponen pengamatan pertumbuhan dan produksi tanaman yang akan dilakukan antara lain terhadap

1. Tinggi tanaman $(\mathrm{cm})$, diukur mulai dari leher akar sampai pada pucuk tertinggi. Pengamatan dilakukan tiap 2 minggu sampai tanaman panen.

2. Luas daun total $(\mathrm{cm})$, diukur panjang dan lebarnya yang telah membuka penuh. Pengamatan dilakukan setiap 2 minggu sampai tanaman panen.

3. Kandungan gula buah semangka segar. Dilakukan dengan analisis laboratorium. Direncanakan dilakukan di laboratorium pangan IPB

4. Rata-rata bobot buah semangka (kg/buah).

\section{- Analisis Data}

Hasil pengamatan dianalisis

secara statistik dengan sidik ragam, dan dilanjutkan dengan Uji Beda Nyata Terkecil (BNT).

\section{HASIL DAN PEMBAHASAN}

Ketersediaan air merupakan faktor penting bagi tanaman yang akan mempengaruhi pertumbuhan dan perkembangan suatu tanaman. Laju pertumbuhan dan perkembangan tanaman akan tercermin melalui pengukuran tinggi tanaman, jumlah maupun luas daun, diameter batang ataupun komponen pertumbuhan lainnya, sedang berat buah dan kualitas buah merupakan komponen tanaman yang dijadikan sebagai alat ukur bagi produksi suatu tanaman.

Berat kering biomassa sering dipandang sebagai wujud dari prosesproses metabolisme yang terjadi di dalam tubuh tumbuhan, sebagai hasil dari proses fotosintesa yang terjadi pada tanaman. Proses fotosintesis dipengaruhi oleh faktor lingkungan terutama faktor iklim dan faktor tanah serta air. Air berperan dalam hal transportasi hara yang dibutuhkan tanaman untuk berbagai proses metabolisme termasuk proses fotosintesis dan juga transportasi hasil fotosintesis ke berbagi bagian tubuh tanaman. Oleh karena itu, ketersediaan air selama proses pertumbuhan tanaman akan sangat menentukan pertumbuhan dan produksi. Gardner et al., (1991) menyatakan bahwa 
berat kering dapat menunjukkan produktifitas tanaman karena $90 \%$ hasil fotosintesis terdapat dalam bentuk berat kering.

Hasil pengukuran pada parameter pertumbuhan diketahui bahwa perlakuan perbedaan lengas tanah $(40,60,80$, dan $100 \%$ kapasitas lapang) berpengaruh terhadap parameter pertumbuhan tanaman dan produksi tanaman semangka. Analisis sidik status lengas tanah yang diujikan belum menunjukan pengaruh nyata terhadap tinggi tanaman pada umur 2 minggu, tetapi berpengaruh nyata terhadap tinggi tanaman umur 4, 6 dan 8 minggu. Rata-rata tinggi tanaman kedelai umur 4, 6 dan 8 minggu setelah tanam disajikan pada Gambar 1.

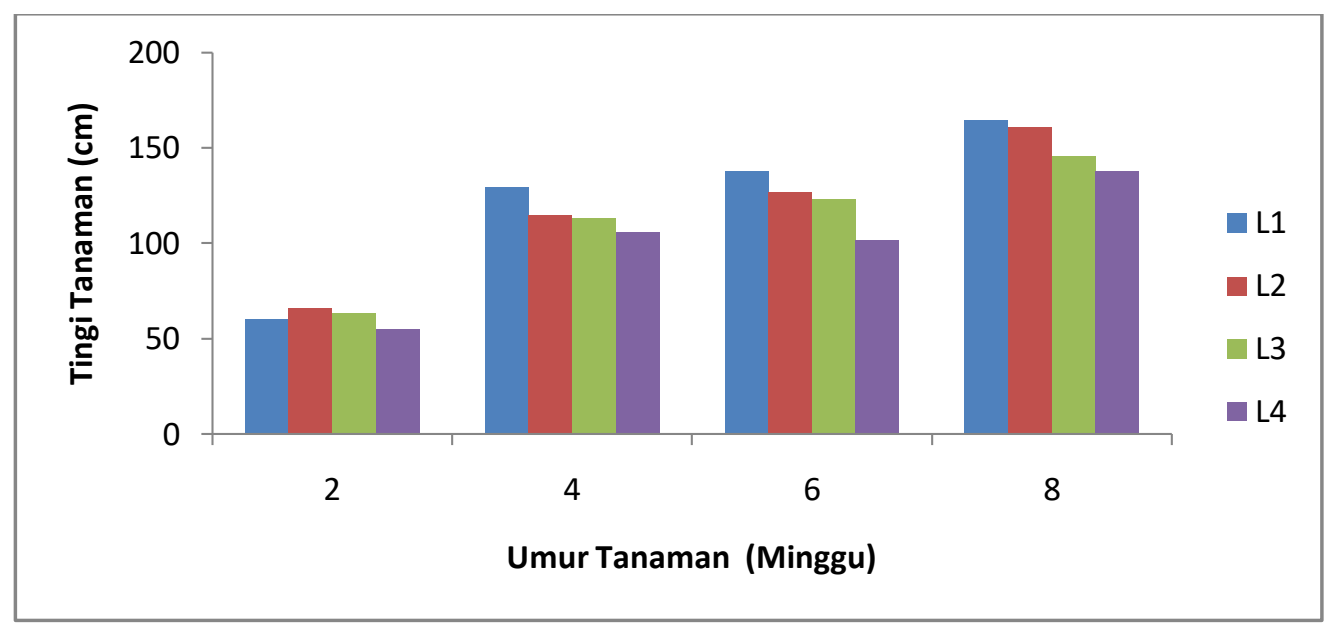

Gambar 1. Pengaruh Lengas Tanah terhadap Tinggi Tanaman Semangka pada Berbagai Umur

Dari Gambar 1 terlihat bahwa tingi tanaman mempunyai kecenderungan berbanding lurus terhadap kandungan lengas tanah. Nilai tinggi tanaman tertinggi dicapai pada lengas tanah $100 \%$, dan menurun hingga dicapai terendah pada lengas tanah $40 \%$. Uji Beda Nyata Terkecil (BNT) pada taraf 95\% (Tabel 1), diketahui bahwa tinggi tanaman pada setiap pengukuran menunjukan trend yang sama yaitu lengas tanah 100\% menghasilkan tinggi tanaman tertinggi dan berbeda nyata dengan perlakuan lengas tanah $40 \%$, tetapi tidak saling berbeda nyata dengan perlakuan lengas tanah $80 \%$ dan $60 \%$.

Tabel 1. Uji BNT Pengaruh status lengas tanah Terhadap Tinggi Tanaman Semangka Umur 4,6 dan 8 Minggu

\begin{tabular}{ccccc}
\hline \multirow{2}{*}{$\begin{array}{c}\text { Status } \\
\text { Lengas }\end{array}$} & \multicolumn{2}{c}{ Tinggi Tanaman $(\mathrm{cm})$} & & BTN 95 \% \\
\cline { 2 - 4 } & 4 Minggu & $\begin{array}{c}6 \\
\text { Minggu }\end{array}$ & $\begin{array}{c}8 \\
\text { Minggu }\end{array}$ & \\
\hline L1 & $129,5^{\mathrm{a}}$ & $137,9^{\mathrm{a}}$ & $164,8^{\mathrm{a}}$ & \\
L2 & $114,7^{\mathrm{ab}}$ & $127,2^{\mathrm{a}}$ & $160,8^{\mathrm{ab}}$ & BNT 4 minggu $=22,18$ \\
L3 & $113,1^{\mathrm{ab}}$ & $123,1^{\mathrm{ab}}$ & $145,9^{\mathrm{ab}}$ & BNT 6 minggu $=25,71$ \\
$\mathrm{~L} 4$ & $105,9^{\mathrm{b}}$ & $101,5^{\mathrm{b}}$ & $137,9^{\mathrm{b}}$ & BNT 8 minggu $=33,58$ \\
\hline
\end{tabular}

Keterangan : Nilai yang diikuti oleh huruf yang sama tidak berbeda nyata pada taraf $95 \%$ 
Analisis sidik menunjukan bahwa status lengas tanah memberikan pengaruh yang nyata terhadap luas daun pada umur semangka 6 minggu dan tidak berpengaruh nyata pada umur 2, 4, dan 8 minggu. Uji BNT pada luas daun pada taraf $95 \%$ (Tabel 2), menunjukkan bahwa pada umur 6 minggu setelah tanam, status lengas tanah $100 \%$ memberikan luas daun tertinggi yang berbeda nyata dengan luas daun pada lengas tanah $40 \%$, tetapi tidak berbeda nyata dengan luas daun pada lengas tanah $80 \%$ dan $100 \%$.

Tabel 2. Uji BNT Pengaruh Status Lengas Tanah terhadap Luas Daun Tanaman Semangka Umur 4, 6, dan 8 Minggu

\begin{tabular}{ccc}
\hline $\begin{array}{c}\text { Status } \\
\text { Lengas }\end{array}$ & $\begin{array}{c}\text { Luas daun } \\
\left(\mathrm{cm}^{2}\right)\end{array}$ & $\begin{array}{c}\text { BTN 95 } \\
\%\end{array}$ \\
\hline L1 & $3.078,2^{\mathrm{a}}$ & \\
L2 & $2.729,6^{\mathrm{ab}}$ & \\
L3 & $2.910,3^{\mathrm{ab}}$ & 1017,65 \\
L4 & $2.049,3^{\mathrm{b}}$ & \\
\hline
\end{tabular}

Keterangan : Nilai yang diikuti oleh huruf yang sama tidak berbeda nyata pada taraf $95 \%$

Proses pembesaran dan pemanjangan sel sangat dipengaruhi oleh ketersediaan air. Air selain memberikan pengaruh terhadap aktifitas hormon, juga berpengaruh terhadap tekanan turgor sel. Ketersediaan air yang rendah $(40 \%$ dan $60 \%$ kapasistas lapang) dapat menurunkan tekanan turgor pada sel. Turgor sel yang rendah akan menurunkan kemampuan sel untuk merenggang, sehingga akan mempengaruhi pertumbuhan dan perkembangannya.

Pertumbuhan tajuk lebih menonjol apabila tersedia unsur nitrogen $(\mathrm{N})$ dan air yang banyak; sedangkan pertumbuhan akar lebih aktif apabila faktor-faktor nitrogen dan air terbatas. Pada tumbuhan yang mengalami cekaman akan mengalokasikan sebagian besar hasil fotosintesisnya ke organ penyimpanan. Ketersediaan air 40\% kapasitas lapang menghasilkan laju pertumbuhan relatif tanaman yang lebih kecil dibandingkan dengan pemberian $80 \%$ ketersediaan air. Proses pembesaran dan pembentangan sel, selain dipengaruhi oleh faktor hormon, juga dipengaruhi oleh turgor sel. Laju pertumbuhan relatif menunjukkan peningkatan berat biomassa tanaman dalam suatu interval waktu dibandingkan dengan berat tanaman awal (Gardner et al., 1991).

Analisis sidik menunjukan bahwa status lengas tanah yang diujikan memberikan pengaruh sangat nyata terhadap bobot buah per buah semangka, sedangkan dosis kalium belum menunjukan pengaruh nyata. Pengaruh lengas tanah terhadap bobot buah semangka pada berbagai umur disajikan pada Gambar 2. 


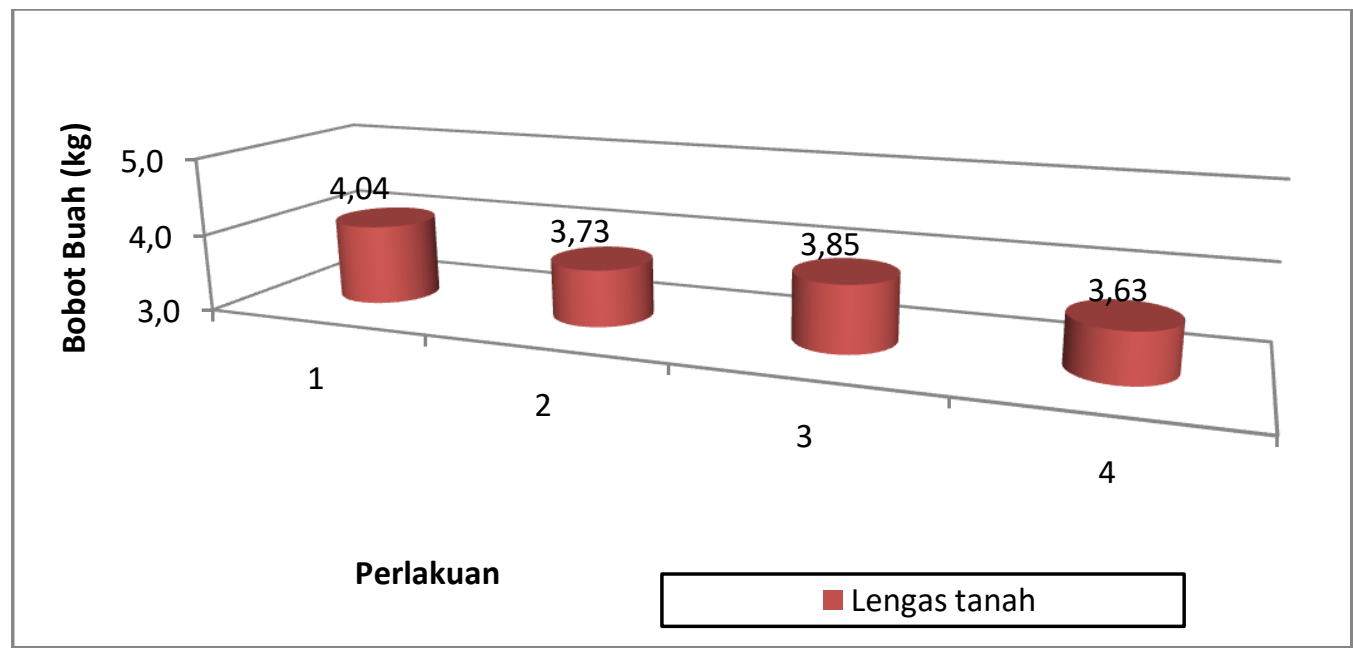

Gambar 2. Pengaruh Lengas Tanah terhadap Bobot Buah Semangka pada Berbagai Umur

Dari Gambar 2 diketahui bahwa status lengas tanah mempunyai pengaruh yang bervariasi terhadap bobot buah. Nampak bahwa bobot terberat terjadi pada perlakuan lengas tanah $100 \%$ dengan bobot perbuah rata-rata $4,04 \mathrm{~kg} / \mathrm{buah}$ dan terendah terjadi pada perlakuan lengas tanah $40 \%$ dengan bobot $3,63 \mathrm{~kg} / \mathrm{buah}$. Ketersediaan air sebesar $100 \%$ kapasitas lapang diduga merupakan tingkat ketersediaan air yang terbaik, karena pada tingkat ketersediaan air ini terjadi akumulasi berat lebih besar dibanding perlakuan lainnya. Ketersediaan air 100\% kapasitas lapang menyebabkan tanah menjadi jenuh oleh air dan diduga hal ini akan memacu penyerapan air dan hara oleh akar-akar tanaman.

\section{KESIMPULAN}

Kesimpulan yang dapat dikemukakan dari kegiatan penelitian ini adalah :

1. Pengaturan status lengas tanah memberikan pengaruh terhadap tinggi tanaman pada umur 4,6 , dan 8 minggu setelah tanam dan berpengaruh nyata pada luas daun umur 6 minggu. Sedangkan dosis kalium belum menunjukkan pengaruh yang berbeda baik pada tinggi tanaman maupun pada luas daun

2. Pada kualitas rasa buah semangka, belum bisa disimpulkan karena telah terjadi kerusakan pada buah semangka akibat serangan penyakit virus.

\section{DAFTAR PUSTAKA}

Agehara, S., and D.D. Warncke. 2005. Soil Moisture and Temperature Effect on Nitrogen Release From Organic Nitrogen Source. Soil Science Society of American Journal, 69.

Bahrun, A. dan Afa, L., 2002. Pengaruh Sistem Pengairan Separuh Daerah Akar Terhadap Pertumbuhan, Hasil dan Kualitas Biji Kedelai yang Ditanam Pada Kondisi Lapang. Laporan Hibah Penelitian Due-Like Batch II Universitas Haluoleo. Kendari.

Bahrun, A. Hasid, R., Muhiddin, dan Erawan, D., 2012. Pengaruh 
Pengairan Separuh Daerah Akar Terhadap Efisiensi Penggunaan Air dan Produksi Kedelai (Glycine max L.) Pada Musim Kemarau. Jurnal Agronomi Indonesia 40 (1):36-41

Erawan, D. 2012. Pengembangan Teknik Pengairan Tanaman Semusim Lahan Kering Berbasis Potensi Air Tanah dan Sumberdaya Iklim untuk Peningkatan Intensitas Tanaman Kedelai. Laporan Penelitian Hibah Bersaing.

Baswarsiati, 2010. Pengelolaan Mangga Podang Urang. Balai Pengkajian Teknologi Pertanian Jawa Timur. Http://Baswarsiati.Wordpress.Com /Page/2/

Darwati, I., M. Rahardjo, S.M.D., dan Rosita. 2000. Produktifitas Som Jawa (Talinum paniculatum Gaertn.) Pada Beberapa Komposisi Bahan Organik. Jurnal Littri 6 (1): 1-4.
Imran, 2005. Budidaya Tanaman Semangka (Citrulus vulgaris S.). Kantor Informasi Pertanian Labuahanbatu.

Kantor Deputi Menegristek Bidang Pendayagunaan dan Pemasyarakatan IImu Pengetahuan dan Teknologi Gedung II Lantai 6 BPP Teknologi, Jl. M.H. Thamrin 8 Jakarta 10340 Tlp. $021 \quad 316$ 9166 69, Fax. 021316 1952, Http://Www.Ristek.Go.ld

Mukhfid, S. 2007. Pengaruh Pemberian Lapisan Lempung Terhadap Peningkatan Lengas Tanah pada Tanah Berpasir. Http://Www.Iptek.Net . Diakses Pada Tanggal 7 Maret 2010.

Surtinah, 2004. Pengaruh Lama Cekaman Air dan Frekuensi Pemberian Gandasil B Terhadap Kualitas Melon. Jurnal Dinamika Pertanian, Vol. XIX No. 3. ISSN 0215-255. 